\title{
Challenging the roles of CD44 and lipolysis stimulated lipoprotein receptor in conveying Clostridium perfringens iota toxin cytotoxicity in breast cancer
}

Katerina D Fagan-Solis ${ }^{1}$, Denise K Reaves ${ }^{1}$, M Cristina Rangel ${ }^{2}$, Michel R Popoff ${ }^{3}$, Bradley G Stiles ${ }^{4}$ and Jodie M Fleming ${ }^{1 *}$

\begin{abstract}
Background: Translational exploration of bacterial toxins has come to the forefront of research given their potential as a chemotherapeutic tool. Studies in select tissues have demonstrated that Clostridium perfringens iota toxin binds to CD44 and lipolysis stimulated lipoprotein receptor (LSR) cell-surface proteins. We recently demonstrated that LSR expression correlates with estrogen receptor positive breast cancers and that LSR signaling directs aggressive, tumor-initiating cell behaviors. Herein, we identify the mechanisms of iota toxin cytotoxicity in a tissue-specific, breast cancer model with the ultimate goal of laying the foundation for using iota toxin as a targeted breast cancer therapy.
\end{abstract}

Methods: In vitro model systems were used to determine the cytotoxic effect of iota toxin on breast cancer intrinsic subtypes. The use of overexpression and knockdown technologies confirmed the roles of LSR and CD44 in regulating iota toxin endocytosis and induction of cell death. Lastly, cytotoxicity assays were used to demonstrate the effect of iota toxin on a validated set of tamoxifen resistant breast cancer cell lines.

Results: Treatment of 14 breast cancer cell lines revealed that LSR+/CD44- lines were highly sensitive, LSR+/CD44+ lines were slightly sensitive, and LSR-/CD44+ lines were resistant to iota cytotoxicity. Reduction in LSR expression resulted in a significant decrease in toxin sensitivity; however, overexpression of CD44 conveyed toxin resistance. CD44 overexpression was correlated with decreased toxin-stimulated lysosome formation and decreased cytosolic levels of iota toxin. These findings indicated that expression of CD44 drives iota toxin resistance through inhibition of endocytosis in breast cancer cells, a role not previously defined for CD44. Moreover, tamoxifen-resistant breast cancer cells exhibited robust expression of LSR and were highly sensitive to iota-induced cytotoxicity.

Conclusions: Collectively, these data are the first to show that iota toxin has the potential to be an effective, targeted therapy for breast cancer.

Keywords: Clostridium perfringens iota toxin, Lipolysis stimulated lipoprotein receptor, CD44, Breast cancer, Endocytosis, Cytotoxicity, Tamoxifen resistance

\footnotetext{
* Correspondence: Jodie.fleming@nccu.edu

'Department of Biology, North Carolina Central University, Durham, NC, USA

Full list of author information is available at the end of the article
} 


\section{Background}

Breast cancer is a heterogeneous disease that varies in etiology, pathophysiology and response to therapy. As a result, patients with disease of similar stage and grade often respond differently to therapy leading to disparate clinical outcomes. Molecular profiles characterizing the various intrinsic breast cancer subtypes, as per gene expression signatures, have been successful for predicting overall survival, relapse, and response to chemotherapy [1-4]. Luminal subtypes are defined by expression of estrogen receptor $\alpha(\mathrm{ER} \alpha)$ and cell cytokeratins (CKs) 8 and 18 $[5,6]$. Basal-like tumors are typically triple-negative (i.e. lacking expression of $\mathrm{ER} \alpha$, progesterone receptor, and human epidermal growth factor receptor 2 (HER2)), yet express basal CKs 5, 14, and/or $17[5,7,8]$. The claudinlow subtype is characterized by low gene expression of junction and adhesion proteins that include claudins 3, 4 and 7, as well as E-cadherin [3]. While these tumors initially respond to chemotherapy, there is a high risk of recurrence and disease progression, consequently leading to poor patient survival [9-11].

Abnormal protein regulation of cell-surface receptors promotes cancer development/progression, and is widely used to determine patient prognosis and dictate therapeutic regime. CD44 and lipolysis stimulated lipoprotein receptor (LSR) are both cell-surface, transmembrane proteins that mediate cellular responses towards their microenvironment. These molecules participate in cell-cell and cell-matrix interactions, as well as regulate cell growth, survival, differentiation, and motility [12-14]. High CD44 levels are a marker for tumor initiating and chemotherapeuticresistant cells in many cancers, including breast $[15,16]$. High CD44-expressing cells have heightened tumorigenicity, self-renewal in vivo, and give rise to functional as well as molecular heterogeneity: properties directly linked to chemotherapeutic-resistant, aggressive cancers [15]. It has also been reported that basal-like tumors contain the highest percentage of CD44-positive cells [17], while high CD44 expression correlates to a basal-like phenotype, increased metastases, and unfavorable prognosis in breast cancer patients [18-20]. Similar to high CD44 levels, increased expression of LSR has been associated with altered gene expression of pathways involved in transformation and tumorigenesis, enhanced proliferation, survival in anchorage independent conditions and promotion of collective cell migration in breast cancer cells [21]. High LSR levels have also been identified as a marker for tumorinitiating and chemotherapeutic-resistant cells [14]. Collectively, these studies highlight a direct role for LSR in driving aggressive breast cancer behavior.

The use of bacterial toxins for selective and efficient cancer therapeutics has been gaining attention due to recent successes in vitro and in vivo [22,23]. Bacterial toxins possess efficient cytotoxic capabilities, making them suitable candidates for gene therapeutic applications towards various cancers [24-31]. Clostridium perfringens iota toxin has various properties that make it a potential candidate for targeted cancer therapy. For instance, like many of the "classic" AB exotoxins, iota toxin is secreted by the bacterium and contains two functionally distinct, subunits not linked in solution [32]. The B subunit (Ib) binds to a cell-surface receptor, facilitating docking and uptake of the enzymatic A subunit (Ia) through receptormediated endocytosis. Ib forms heptamers on the cell surface and creates pores within an acidified endosome membrane enabling release of Ia into the cytosol. The Ia molecule mono-ADP-ribosylates $G$ actin, subsequently preventing $\mathrm{F}$ actin assembly that leads to overt rounding of cells and death [32-34].

Recent studies have implicated LSR and CD44 as functional receptors, or co-receptors, mediating iota toxin binding to host cells $[35,36]$. However, the relationship between these cell-surface proteins with respect to promotion of iota cytotoxicity is still unclear, given the various model systems used during these investigations. In the present study, we investigated the role of LSR and CD44 in a tissue-specific manner by identifying which protein mediates the cytotoxic processes specific to breast cancer. Ultimately, our future goal is to evaluate the potential of using iota toxin as an adjuvant, targeted therapy for breast cancers that may be less toxic than current available treatments.

\section{Results}

Relationship of LSR and CD44 expression levels in breast cancer subtypes to iota toxin sensitivity

From the perspective of a protein-based treatment tool, $C$. perfringens iota toxin is relatively unexplored yet possesses promising potential for targeting breast cancer, as recent evidence now implicates LSR and CD44 as functional facilitators of iota cytotoxicity $[35,36]$. Thus, identifying the precise mechanisms of interaction between iota toxin with LSR and CD44 is a necessary step towards developing targeted therapies for breast cancer. Previous cancer studies have shown that LSR is positively correlated with ER $\alpha$ expression, tumor initiating cells, and chemoresistance $[14,21]$. Others have shown that high CD44 expression correlates to a basal-like phenotype and unfavorable prognosis in breast cancer patients [17-19]. Given this, we first assessed LSR and CD44 expression in a panel of well-characterized breast cancer cell lines. LSR was detectable in the majority of luminal and basal-like subtypes, while the claudin-low lines had little to no expression of LSR (Figure 1A,B). Conversely, CD44 expression was readily detectable in claudin-low lines while basal-like and luminal lines had little to below detectable expression levels via western blot analysis. 


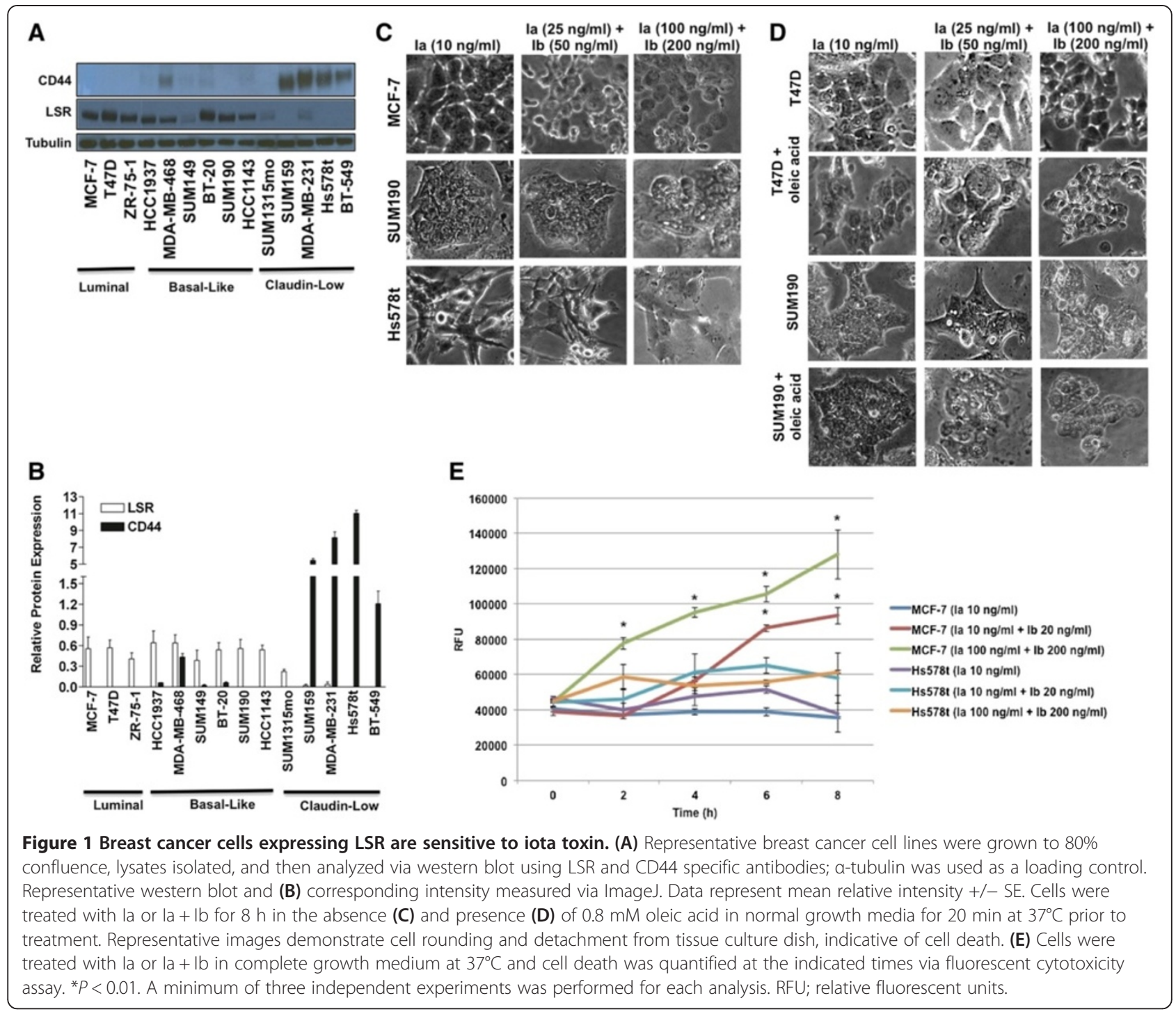

To further understand the role LSR and CD44 play in breast cancer susceptibility to iota toxin, we evaluated the effects of toxin exposure over time. Cells were treated with control (Ia only) or with varying concentrations of Ia and $\mathrm{Ib}$ as indicated (Figure 1C), under normal growth conditions. Toxin sensitivity, easily observed by robust cell rounding and altered morphology, was documented at 0 , $1,2,4,6$, and $8 \mathrm{~h}$ post treatment. Results show that LSR+/CD44- lines were highly sensitive, LSR+/CD44+ lines were moderately sensitive, and LSR-/CD44+ lines were interestingly resistant to the cytotoxic effects of iota toxin in both a time and dose-dependent manner (Figure 1C; Table 1; cell rounding quantified in Additional file 1: Figure S1A). Furthermore, in fibroblasts and hepatocytes, binding of LSR to free fatty acids induces a conformational change that mediates binding of apoproteins B- and E-containing lipoproteins, leading to their subsequent internalization and degradation [37-39]. Thus, to further verify that iota toxin sensitivity is conveyed through LSR, we treated two LSR + cell lines moderately sensitive to iota toxin with oleic acid. Iota cytotoxicity was enhanced by oleic acid (Figure 1D; Table 2; cell rounding quantified in Additional file 1: Figure S1A).

To confirm the observed cell death, cytotoxicity assays were performed on highly sensitive, LSR+/CD44- MCF-7 and resistant LSR-/CD44+ Hs578t cells when treated with low and high concentrations of iota toxin (Figure 1E). Results indicated that highly sensitive MCF-7 cells had a significant increase in cytotoxicity in a time- and dose- dependent manner when challenged with iota toxin $(P<0.01)$. However, resistant Hs578t cells did not have significant changes in cytotoxicity compared to controls treated with Ia only (Figure 1E). No significant alteration in expression or activation (via cleavage) of 
Table 1 lota toxin sensitivity in a breast cancer cell line panel

\begin{tabular}{|c|c|c|c|c|c|c|}
\hline & Cell line & la $(10 \mathrm{ng} / \mathrm{ml})$ & $\begin{array}{c}\text { la }(10 \mathrm{ng} / \mathrm{ml})+ \\
\text { lb }(20 \mathrm{ng} / \mathrm{ml})\end{array}$ & $\begin{array}{c}\text { la }(25 \mathrm{ng} / \mathrm{ml})+ \\
\text { lb }(50 \mathrm{ng} / \mathrm{ml})\end{array}$ & $\begin{array}{l}\text { la }(50 \mathrm{ng} / \mathrm{ml})+ \\
\text { lb }(100 \mathrm{ng} / \mathrm{ml})\end{array}$ & $\begin{array}{c}\text { la }(100 \mathrm{ng} / \mathrm{ml})+ \\
\text { lb }(200 \mathrm{ng} / \mathrm{ml})\end{array}$ \\
\hline \multirow{3}{*}{ Luminal } & MCF-7 & - & + & + & ++ & ++ \\
\hline & T47D & - & + & + & + & ++ \\
\hline & ZR-75-1 & - & + & + & ++ & ++ \\
\hline \multirow{6}{*}{ Basal-like } & HCC1937 & - & ++ & ++ & ++ & ++ \\
\hline & MDA-MB-468 & - & + & + & ++ & ++ \\
\hline & SUM149 & - & - & - & + & ++ \\
\hline & BT-20 & - & - & + & + & + \\
\hline & SUM190 & - & - & + & + & + \\
\hline & HCC1143 & - & ++ & ++ & ++ & ++ \\
\hline \multirow{5}{*}{ Claudin-low } & SUM1315mo & - & + & + & + & + \\
\hline & SUM159 & - & - & - & - & - \\
\hline & MDA-MB-231 & - & - & - & + & + \\
\hline & $\mathrm{Hs578T}$ & - & - & - & - & - \\
\hline & BT-549 & - & - & - & - & - \\
\hline
\end{tabular}

(-) Resistant, 0 to $10 \%$ cell rounding; (+) Sensitive, 11 to $50 \%$ cell rounding; (++) Highly Sensitive, $>50 \%$ cell rounding. Toxin Sensitivity recorded at $8 \mathrm{~h}$ post treatment.

cytochrome c or caspase-3 was detected via western blot analysis, suggesting that cell death was not mediated through these apoptotic pathways (data not shown). Collectively, these data suggest that expression of LSR and not CD44 is required for sensitivity of breast cancer cells to iota toxin.

\section{Glycosylation status of LSR and CD44 relative to iota toxin sensitivity}

It is well established that glycosylation is necessary for proper functioning of CD44 in certain pathways [12,40-42]. While the glycosylation status of LSR is not characterized, sequence analysis indicates LSR contains residues as potential $\mathrm{N}$-glycosylation sites. Thus, to determine whether glycosylation of LSR and/or CD44 plays a role in iota toxin sensitivity, we first assessed the glycosylation status of LSR. MCF-7 cells were treated with vehicle control or de-glycosylation agents Tunicamycin or Swainsonine $(25 \mu \mathrm{g} / \mathrm{ml}$, each). Western blot analysis indicated no shift in electrophoretic migration by SDS PAGE, suggesting that LSR was not heavily glycosylated
(Additional file 2: Figure S2A). To verify that the deglycosylating agents were functioning properly in the same cell line, expression of a known glycoprotein (E-cadherin) was assessed $[43,44]$. Treatment of MCF-7 cells with tunicamycin or swainsonine decreased the levels of glycosylated E-cadherin (top band) and increased the non-glycosylated (bottom) bands, thus confirming activity of the de-glycosylation agents (Additional file 2: Figure S2A). To confirm that the de-glycosylation agents did not affect the role of LSR cytotoxicity, LSR+/CD44MCF-7 cells were cultured with or without Tunicamycin, followed by iota toxin. As shown in Additional file 2: Figure S2B and Additional file 3: Table S1, sensitivity of breast cancer cells to iota toxin was not altered by tunicamycin, suggesting that glycosylation does not play a role in toxin susceptibility.

Knowing that glycosylation is necessary for CD44 function in certain pathways [12,40-42], we sought to determine whether glycosylation was required to convey toxin resistance. When LSR-/CD44+ Hs578t cells were treated as described above, sensitivity to iota toxin was

Table 2 lota toxin sensitivity of breast cancer cells following oleic acid treatment

\begin{tabular}{|c|c|c|c|c|c|}
\hline Cell line & la $(10 \mathrm{ng} / \mathrm{ml})$ & $\begin{array}{l}\text { la }(10 \mathrm{ng} / \mathrm{ml})+ \\
\text { lb }(20 \mathrm{ng} / \mathrm{ml})\end{array}$ & $\begin{array}{l}\text { la }(25 \mathrm{ng} / \mathrm{ml})+ \\
\text { lb }(50 \mathrm{ng} / \mathrm{ml})\end{array}$ & $\begin{array}{l}\text { la }(50 \mathrm{ng} / \mathrm{ml})+ \\
\text { lb }(100 \mathrm{ng} / \mathrm{ml})\end{array}$ & $\begin{array}{l}\text { la }(100 \mathrm{ng} / \mathrm{ml})+ \\
\text { lb }(200 \mathrm{ng} / \mathrm{ml})\end{array}$ \\
\hline T47D & - & + & + & + & ++ \\
\hline T47D + Oleic acid & - & ++ & ++ & ++ & ++ \\
\hline SUM190 & - & - & + & + & + \\
\hline SUM190 + Oleic acid & - & - & + & ++ & ++ \\
\hline
\end{tabular}

$(-)$ Resistant, 0 to $10 \%$ cell rounding; (+) Sensitive, 11 to $50 \%$ cell rounding; (++) Highly Sensitive, $>50 \%$ cell rounding. Toxin Sensitivity at $8 \mathrm{~h}$ post treatment. 
not altered, suggesting that deglycosylation of CD44 does not affect sensitivity to iota cytotoxicity (Additional file 2: Figure S2B and Additional file 3: Table S1).

Previous studies have determined that LSR and CD44 have multiple variants/isoforms that occur in cancer [45-47]. We performed variant specific qRT-PCR analysis in order to determine whether there was a correlation between iota toxin sensitivity and expression of LSR and/or CD44 variants. Although expression of LSR and CD44 variants varied among cell lines, there was no correlation between expression of LSR and/or CD44 variants with sensitivity to iota toxin (Additional file 4: Figure S3 and Additional file 5: Figure S4).

\section{LSR expression directly mediates iota toxin sensitivity in breast cancer cells}

To directly test the ability of LSR to convey iota toxin cytotoxicity, we stably knocked down LSR in MCF-7 and MDA-MB-231 cells resulting in decreased expression
(64\% and 46\%, respectively) compared to control (Figure 2A). LSR knockdown lines were subjected to treatment with iota toxin, and as shown in Figure 2A and Table 3, reduced LSR expression in MCF-7 cells resulted in decreased sensitivity compared to scrambled control. This result could be due to the high expression of LSR in MCF-7 cells, suggesting there were still sufficient receptor numbers on the surface to facilitate intoxication. Conversely, knockdown of LSR in MDA-MB-231 cells, which have significantly lower basal levels of LSR expression (Figure 1A) resulted in a significant decrease in toxin sensitivity compared to scrambled, suggesting that reduction of LSR diminishes iota toxin sensitivity (Figure 2A; cell rounding quantified in Additional file 1: Figure S1B). To confirm our findings, LSR was overexpressed in two iota toxin resistant (LSR-/CD44+) cell lines, Hs578t and SUM159 (Figure 2B), and then treated with iota toxin. It is of note that overexpression of LSR in Hs578t and SUM159 cells did not increase sensitivity to iota toxin.

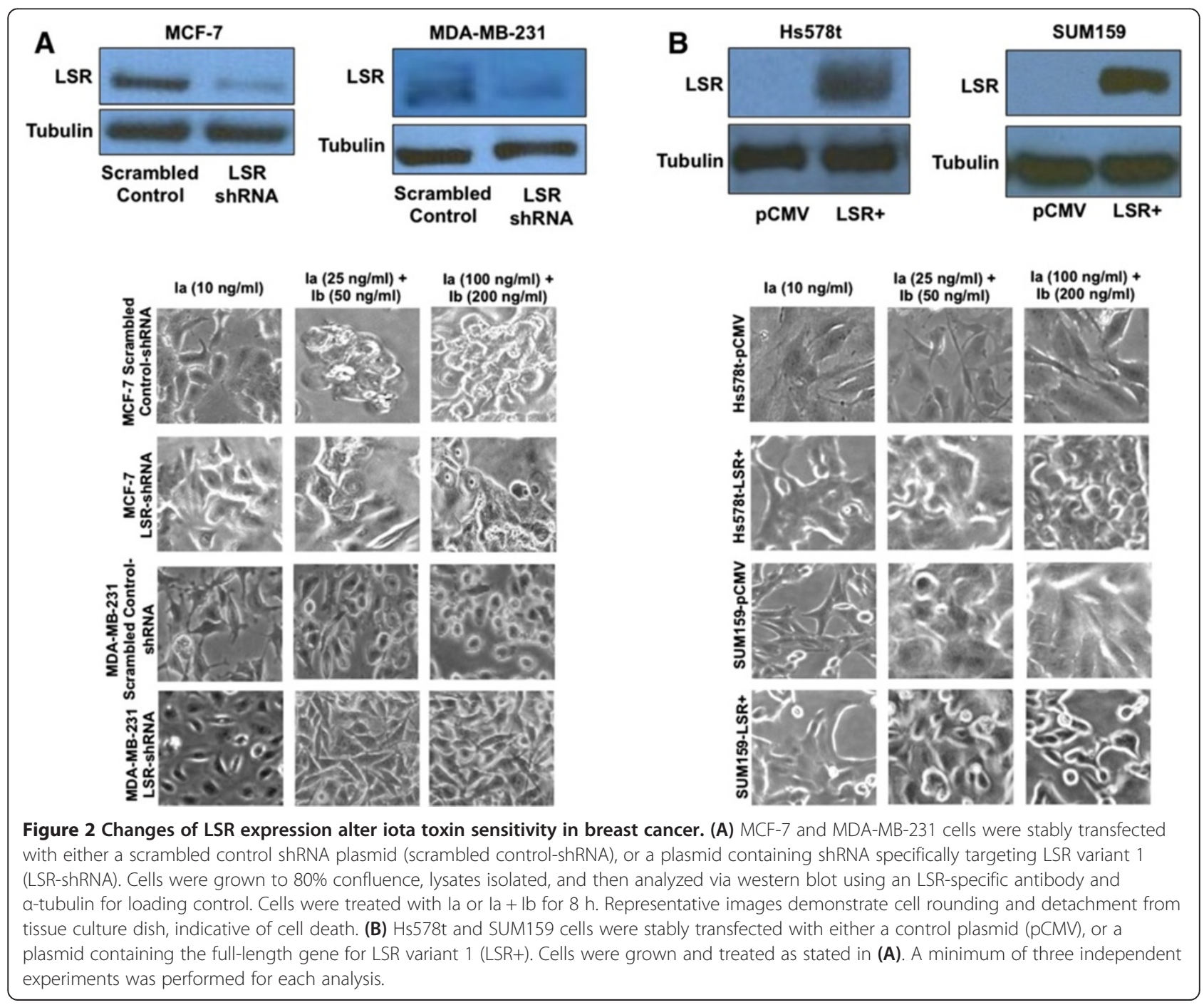


Table 3 lota toxin sensitivity in LSR overexpressing and knockdown cells

\begin{tabular}{|c|c|c|c|c|c|c|}
\hline & Cell line & la $(10 \mathrm{ng} / \mathrm{ml})$ & $\begin{array}{c}\text { la }(10 \mathrm{ng} / \mathrm{ml})+ \\
\text { lb }(20 \mathrm{ng} / \mathrm{ml})\end{array}$ & $\begin{array}{c}\text { la }(25 \mathrm{ng} / \mathrm{ml})+ \\
\text { lb }(50 \mathrm{ng} / \mathrm{ml})\end{array}$ & $\begin{array}{l}\text { la }(50 \mathrm{ng} / \mathrm{ml})+ \\
\text { lb }(100 \mathrm{ng} / \mathrm{ml})\end{array}$ & $\begin{array}{c}\text { la }(100 \mathrm{ng} / \mathrm{ml})+ \\
\text { lb }(200 \mathrm{ng} / \mathrm{ml})\end{array}$ \\
\hline \multirow{7}{*}{ Overexpressing } & SUM1315mo-CMV & - & - & - & - & + \\
\hline & SUM1315mo-CD44+ & - & - & - & - & - \\
\hline & SUM1315mo-LSR+ & - & - & + & + & ++ \\
\hline & SUM159-CMV & - & - & - & - & - \\
\hline & SUM159-LSR+ & - & - & - & - & - \\
\hline & $\mathrm{Hs} 578 \mathrm{t}-\mathrm{CMV}$ & - & - & - & - & - \\
\hline & Hs578t-LSR+ & - & - & - & + & + \\
\hline \multirow{6}{*}{ Knockdown } & MCF-7 Scrambled Control & - & + & + & ++ & ++ \\
\hline & MCF-7 LSR shRNA & - & + & + & + & + \\
\hline & SUM1315mo Control & - & + & + & + & + \\
\hline & SUM1315mo-LSR shRNA & - & - & - & - & - \\
\hline & MDA-MB-231 Scrambled Control & - & - & - & + & + \\
\hline & MDA-MB-231 LSR shRNA & - & - & - & - & - \\
\hline
\end{tabular}

(-) Resistant, 0 to $10 \%$ cell rounding; (+) Sensitive, 11 to $50 \%$ cell rounding; (++) Highly Sensitive, $>50 \%$ cell rounding. Toxin Sensitivity at $8 \mathrm{~h}$ post treatment.

While there were a few cells that succumbed to the toxin effects, the vast majority of the cell population remained resistant to the toxin (Figure 2B; Table 3; cell rounding quantified in Additional file 2: Figure S2B). These data suggested that introduction of LSR into LSR negative breast cancer cells does not increase sensitivity to iota toxin.

\section{CD44 expression conveys resistance to iota toxin in breast cancer cells}

Given that introduction of LSR into $\mathrm{LSR}^{\text {low }} / \mathrm{CD} 44^{\text {high }}$ expressing, claudin-low cell lines did not increase sensitivity to iota toxin and that CD44 can facilitate iota cytotoxicity in non-breast cancer cells $[35,36]$, we sought to determine if iota toxin binding to CD44 was resulting in resistance to cytotoxicity. The claudin-low breast cancer cell line SUM1315mo was chosen as a model because they are $\mathrm{LSR}^{\text {low }} / \mathrm{CD} 44^{\text {low }}$ and importantly, sensitive to iota toxin. Consistent with our prior results, stable knockdown of LSR in SUM1315mo cells (approximate 83\% reduction in LSR; Figure 3A) significantly decreased toxin sensitivity in a time and dose dependent manner while overexpression significantly increased cytotoxicity compared to control cells $(P<0.05$; Figures $3 B, C$ and 4 ; cell rounding quantified in Additional file 1: Figure S1C,D). This was contradictory to our data with CD44 $4^{\text {high }}$ expressing Hs578t and SUM159 cells. In the absence of CD44, overexpression of LSR in SUM1315mo cells increased sensitivity to iota toxin. This supports the hypothesis that CD44 expression in breast cancer cells may provide resistance to iota toxin. To directly test the functional role of CD44 in conveying toxin sensitivity, CD44 was overexpressed in our model (Figure $4 \mathrm{~B}$ ) and then treated with iota toxin. Reintroduction of CD44 into SUM1315mo cells indeed resulted in resistance to iota toxin $(P<0.05$; Figure 4C, D; cell rounding quantified in Additional file 1: Figure S1E). Sensitivity of these cells was reduced to control levels even in the presence of high concentrations of iota toxin, directly demonstrating that CD44 expression conveys resistance to intoxication.

\section{CD44 inhibits endocytosis of iota toxin in breast cancer cells}

While CD44 promotes iota cytotoxicity in non-breast cancer cells $[35,36]$, our data is the first to illustrate that CD44 may actually confer resistance to iota toxin in breast cancer. To determine the mechanisms of resistance conveyed by CD44, we further investigated aspects of toxin endocytosis via lysosome formation. LSR knockout and knockin cells (SUM1315mo), as well as CD44 knockin cells were treated with Ia only (control) or a high concentration of iota toxin (Ia $100 \mathrm{ng} / \mathrm{ml}+\mathrm{Ib} 200 \mathrm{ng} / \mathrm{ml}$ ). When challenged with iota toxin, significantly lower levels of lysosomes were evident in LSR knockout cells compared to scramble control cells $(P<0.001$; Figure $5 \mathrm{~A})$. Correspondingly, LSR-overexpression increased the number of lysosomes versus controls. Moreover, CD44-overexpression in the cells directly demonstrated a significant reduction in lysosome formation when challenged with the toxin compared to controls and LSR + cells $(P<0.001)$. These data correlate LSR expression with enhanced toxin-stimulated lysosome formation and establish a mechanism for CD44based inhibition via lysosome formation.

To confirm our results of toxin endocytosis and incorporation into lysosomes, cells were treated with or without iota toxin, washed, and the lysates analyzed for internalized iota toxin (Ib) via western blotting. Similar to results observed with lysosome formation, knockdown 


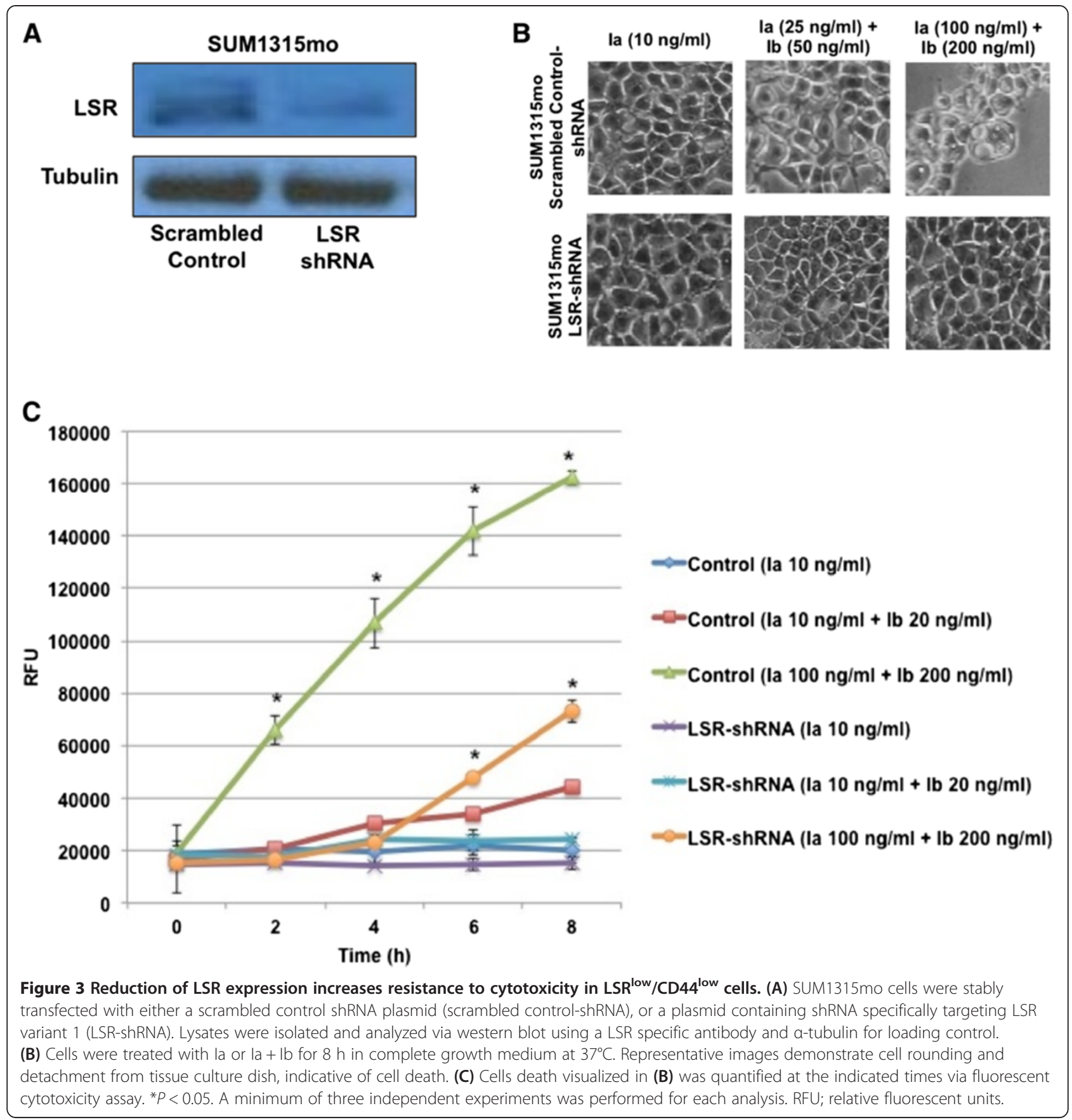

of LSR significantly decreased levels of intracellular toxin compared to scrambled control, while overexpression increased toxin endocytosis $(P<0.05$; Figure $5 \mathrm{~B})$. These data strongly confirm that LSR is not only a critical receptor for iota toxin cytotoxicity in breast cancer, but that it increases endocytosis of the toxin. Interestingly, reintroduction of CD44 resulted in a significant decrease in detectable Ib when compared to the control or LSRoverexpressing cells. This indicates that expression of CD44 in breast cancer cells confers iota toxin resistance by inhibiting endocytosis, a role not previously defined for CD44.

lota toxin has cytotoxic effects on tamoxifen-resistant breast cancer

Cellular chemotherapeutic resistance is a major factor involved in poor response and reduced survival in breast cancer patients [48]. A common and successful targeted therapy for ER $\alpha$-positive breast cancers includes antiestrogen drugs, such as tamoxifen. However, an emerging 


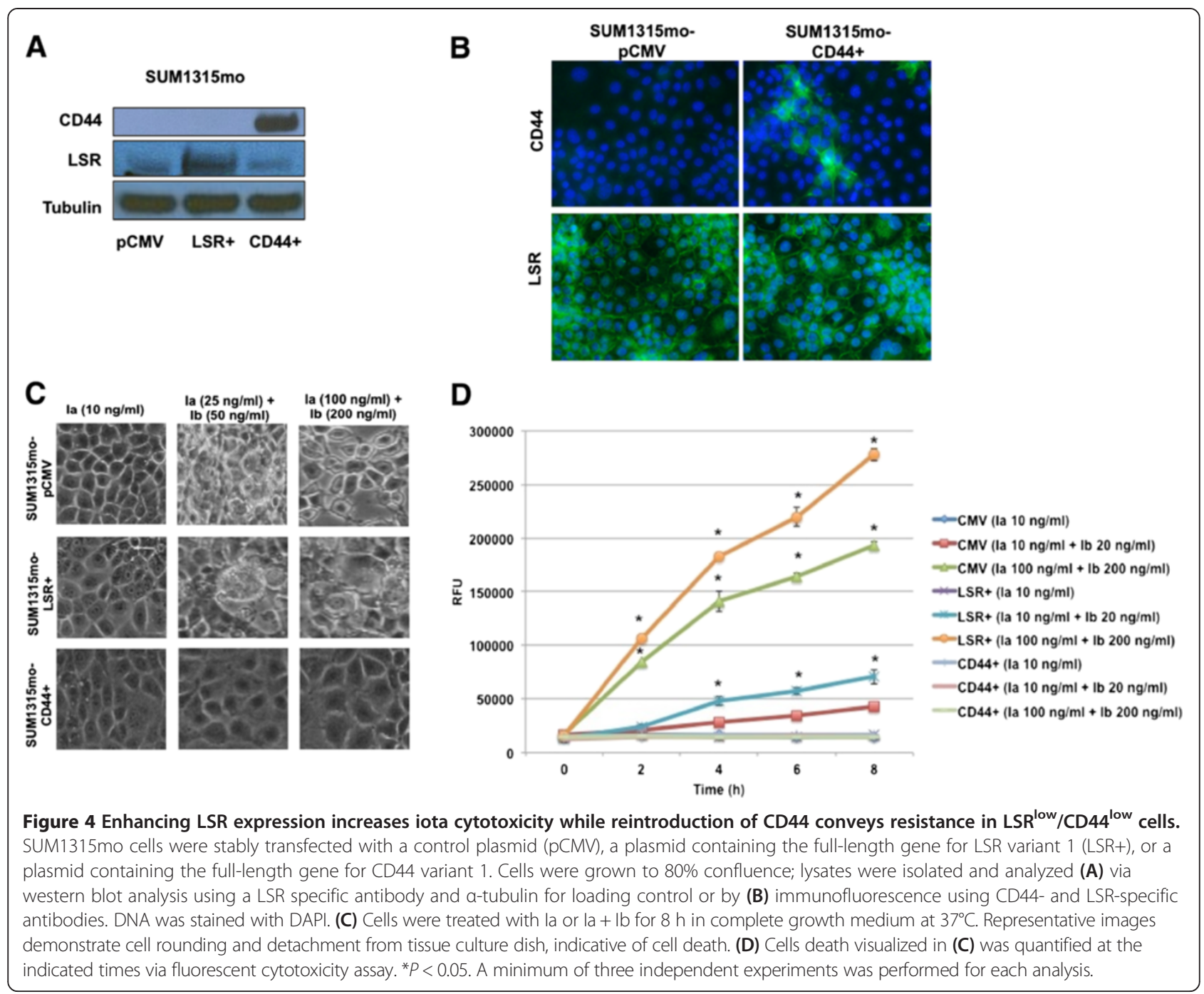

problem has been that $\sim 33 \%$ of patients given tamoxifen therapy for five years develop recurrent tumors, and of those, 26\% subsequently die [49-51]. Previous studies in our laboratory show that LSR is positively correlated with ER $\alpha$ expression [21]. Tamoxifen-resistant breast cancers are derived from ER $\alpha$-positive tumors, and thus are likely to have high expression of LSR making them potential candidates for successful treatment with iota toxin. Ultimately, such information opens up the possibility that iota toxin represents a novel, targeted therapeutic for breast cancer.

To directly evaluate iota toxin susceptibly of tamoxifenresistant, MCF-7-derived breast cancer cell lines, ER $\alpha$ positive TMX2-4 and TMX2-11, as well as ER $\alpha$-negative TMX2-28, cells were assessed for LSR and CD44 expression. All three tamoxifen-resistant lines expressed LSR, but not CD44 (Figure 6A), via western blot analysis. When treated with iota toxin, all three tamoxifen-resistant lines were readily susceptible (Figure $6 \mathrm{~B}, \mathrm{C}$; ${ }^{*} P<0.05$; cell rounding quantified in Additional file 1: Figure S1F). These data suggest that iota toxin has the potential as a targeted therapy for tamoxifen-resistant breast cancers.

\section{Discussion}

The objective of the current study was to further characterize the roles of LSR and CD44 during C. perfringens iota cytotoxicity on breast cancer cells. Two studies have indicated that iota toxin has the ability to bind to membrane-bound proteins, CD44 and LSR [35,36]. Complementary to the study by Papatheodorou et al. [35], in HAP-1 and HeLa cells, treatment of 14 breast cancer cell lines in our study show that those expressing LSR were sensitive to iota toxin. Additionally, consistent with reports in fibroblasts and hepatocytes demonstrating enhanced LSR-mediated endocytosis in the presence of oleic acid, treatment of LSR-expressing breast cancer cells with oleic acid increased sensitivity to iota toxin. However, our data presents an interesting mechanism in breast tissue 


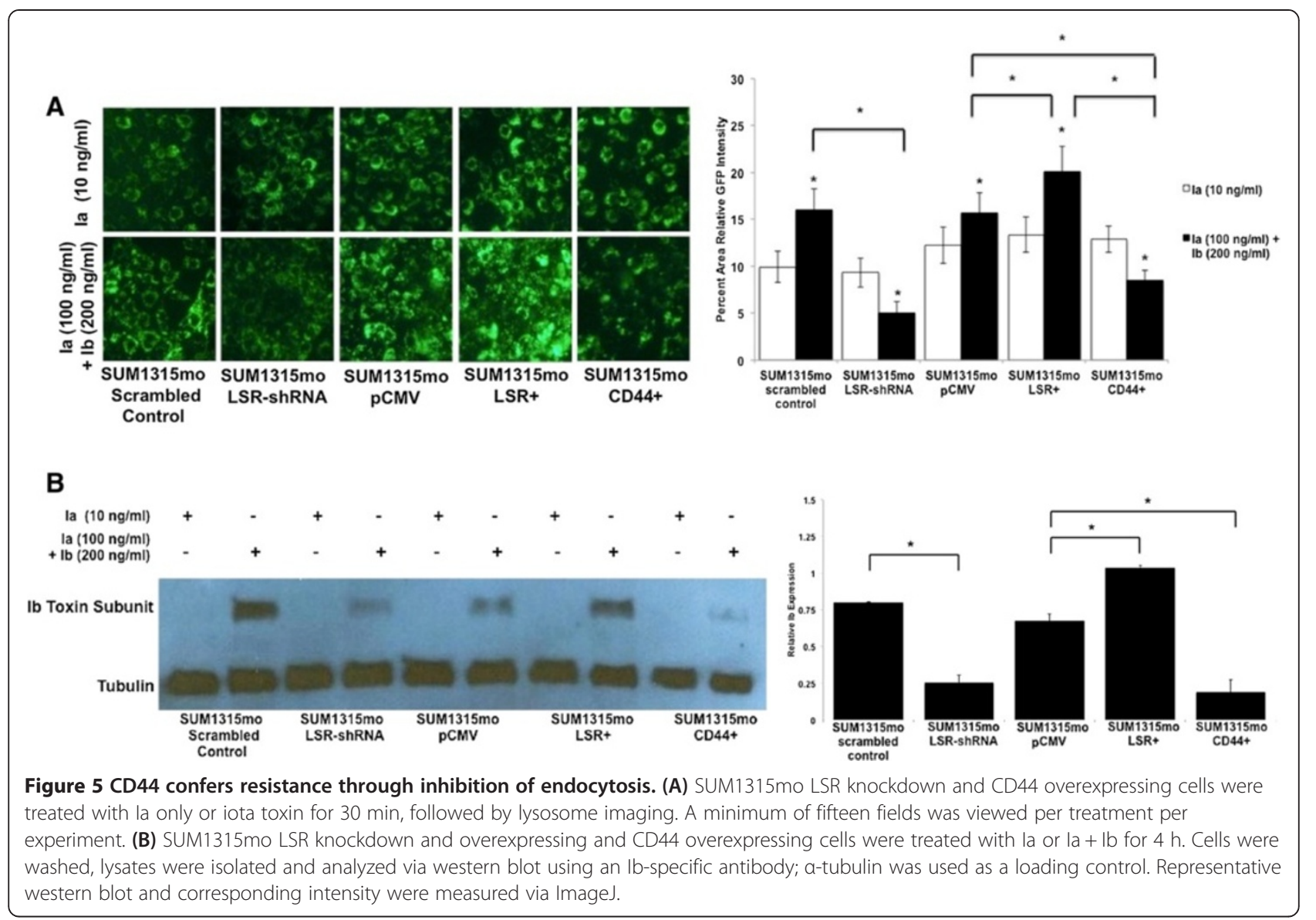

that is contrary to reports in other tissues. Remarkably, breast cancer cells expressing CD44 displayed varying levels of toxin resistance. Specifically, LSR+/CD44- lines were highly sensitive, LSR+/CD44+ lines were slightly sensitive, and LSR-/CD44+ lines were resistant to the cytotoxic effects of iota toxin. Consistent with this observation, toxin sensitivity was highest in the luminal cell lines, median in basal-like, and lowest in claudinlow lines, corresponding to their reciprocal expression levels of LSR and CD44. Toxin sensitivity among the various basal-like cell lines was heterogeneous which can be attributed, in part, to the individual cell lines diverse expression of both CD44 and LSR levels. It is important to note that while our data are unlike those found in the study by Wigelsworth et al. [36], where they found CD44 expression promotes iota intoxication in Vero (African green monkey kidney) and human melanoma (RPM) cell cultures (in vitro), as well as in mice (in vivo lethality), the authors state that the cells they used contained LSR. They further investigated interaction between LSR and CD44 via co-precipitation experiments, showing no interaction between the proteins; however, they acknowledge that CD44 and LSR may co-facilitate entry of iota toxin into cells via an unknown mechanism.
This is highlighted by the fact that the authors were unable to completely block intoxication by anti-CD 44 and high amounts of toxin still cause cytotoxicity in CD44- cells [36].

Our current study suggests that the cellular response to iota toxin is tissue-specific, and for reasons not totally understood at this time. As CD44 serves many roles for a cell, and appears as many different isotypes, there clearly needs to be further study to determine more definitively the role(s) played by CD44 during iota intoxication. In fact, this current study reveals that CD44 prevents endocytosis of iota toxin and conveys cytotoxic resistance in breast cancer cells. Other studies have shown that posttranslational modifications of CD44 may also affect CD44 function and endocytosis [12,40-42]. In our current study, we show that treatment with deglycosylation agents did not appreciably affect iota toxin cytotoxicity; however, other modifications unknown to us may be involved. For example, inhibition of CD44 palmitylation has no effect on CD44 binding to hyaluronan, yet there is inhibition of hyaluronan internalization [52]. Moreover, the posttranslational modifications and variants of LSR may also play a role in tissue-specific toxin endocytosis. While currently little is known about these variants and post-translational 


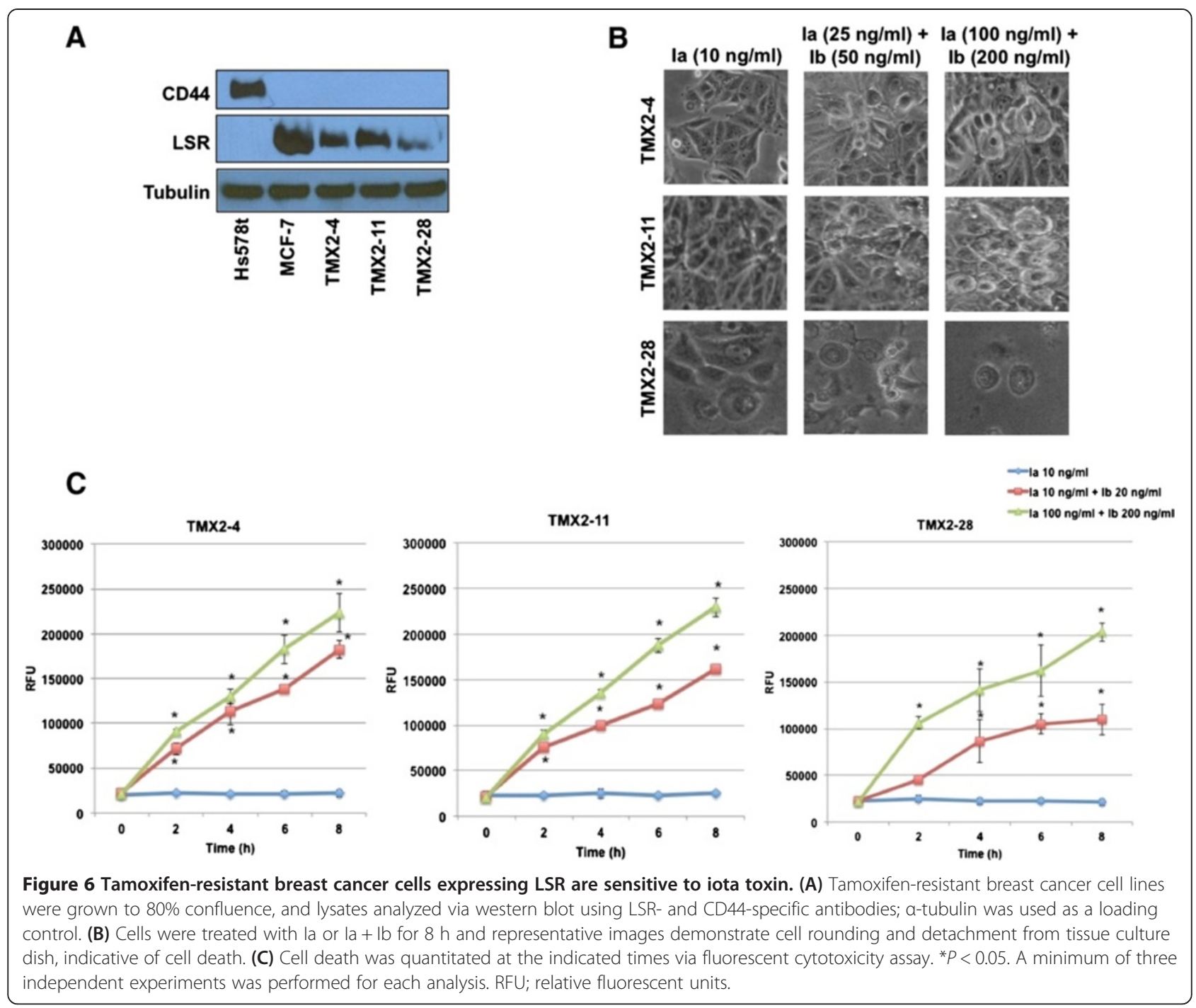

modifications of LSR, one study identifies at least one phosphorylated site ( $\mathrm{Ser}^{435}$ within RPRARpS ${ }^{435}$ VDAL) that affects binding of 14-3-3, a cytosolic adaptor protein involved in mediating signaling pathways by binding to phosphoserine-containing proteins [53].

Identifying the precise mechanisms of interaction between iota toxin and cell-surface proteins, as well as the subsequent downstream intracellular pathways that lead to cytotoxicity, are necessary steps in developing targeted therapies for breast cancer. Earlier studies show that in Vero cells, iota toxin enters through clathrinindependent endocytosis mechanisms, is dependent upon dynamin, and regulated by Rho-GDI [54]. Similarly, both CD44 and LSR have been proposed to be internalized via clathrin-independent mechanisms in non-breast tissues [36]. Central to our studies, breast cancer stem/tumorinitiating cells have a significantly higher rate of clathrinindependent endocytosis [55]. We have also previously shown that cells expressing high levels of LSR have enhanced cancer stem cell-like properties [21], thus collectively suggesting that iota toxin may have heightened effects upon breast cancer stem cells.

Nagahama et al. [56] describe the dynamics of intracellular trafficking of the Ib component of iota toxin. Through their study of MDCK cells, they found that post-internalization involves Ia escape from early endosomes into the cytosol and subsequent ADP-ribosylation of $\alpha$ - and $\beta$-actin. The majority of Ib goes through the endocytotic pathway into lysosomes and is degraded. A small percentage of $\mathrm{Ib}$ reportedly recycles back to the plasma membrane, which they suggest extends Ia entry into the target cell $[56,57]$. In line with this mechanism, our study revealed Ib within the lysates of LSR + cells treated with iota toxin and enhanced lysosome formation, demonstrating Ib internalization. While we did not presently analyze whether cells treated with low levels of 
toxin had a percentage of Ib recycled to the cell-surface, this strengthens the potential of using iota toxin as a therapeutic. Recycled Ib to the plasma membrane may further sensitize the cancer cell to a secondary toxin (Ia) treatment, thereby potentially eradicating any remaining cells.

Tamoxifen and aromatase inhibitors (AI) are commonly used to treat ER $\alpha$-positive breast cancers as these therapies inhibit estrogenic signaling, ultimately leading to inhibition of cell proliferation and survival involving activated apoptotic pathways [58-61]. Tamoxifen and AI resistance are emergent clinical problems that induce phenotypic changes in tumor cells, including decreased apoptosis as well as increased proliferation and invasion [58-61]; however, the molecular mechanisms behind resistance are largely unknown. As we show in this current study, iota toxin interacts with LSR to induce cell death and LSR expression is correlated with ER $\alpha$-positive breast cancers [21]. Our laboratory is currently testing the potential of iota toxin as an adjuvant therapy for women with ER $\alpha$-positive, tamoxifen- and AI-resistant breast cancers. We have previously shown a multifaceted role of LSR in directing breast cancer cell behavior. For example, overexpression of LSR enhances cell proliferation and migration, as well as stimulates cancer-stem cell related properties such as survival in anchorage-independent conditions [21]. We also show that LSR expression significantly correlates with ER $\alpha$ expression in primary breast cancer biopsies [21]. In the current study, we show that tamoxifen-resistant breast cancer cell lines also express LSR and are sensitive to iota toxin-induced cytotoxicity. Iota toxin evidently circumvents the prosurvival mechanisms employed in anti-hormone resistant breast cancers by exploiting necrotic pathways.

Bacterial immunotoxins have been used in clinical trials to successfully treat hematological malignancies and solid tumors, as well as used as an adjuvant therapy targeting mesothelin-expressing mesothelioma, ovarian, or pancreatic cancer [62-66]. Immunotoxins derived from Pseudomonas exotoxin A, or plant-based ricin, subunits attached to antibody fragments have been evaluated in Phase I and II clinical trials for treating solid tumors. These trials revealed that immunotoxins could specifically target cell-surface antigens expressed at high levels in tumors. Another Phase I clinical trial, conducted by von Minckwiz and colleagues, used a single-chain immunotoxin targeting Her2 from eighteen Her2-expressing cancer patients. Intratumoral injections of immunotoxin successfully reduced tumor size [64,65]. Additionally, studies in nude mice with mesothelin-expressing tumor xenografts reveal enhanced therapeutic responses when taxon, or other cancer drugs, are administered in combination with SS1P, a high-affinity immunotoxin that targets mesothelin [66]. A Phase I trial was subsequently initiated, where mesothelin-positive and recurrent or unresectable mesothelioma, ovarian, or pancreatic cancer patients were infused with SS1P continually for ten days. The recombinant immunotoxin was well tolerated by patients and showed modest clinical benefit. Our current study revealed that iota toxin specifically targets LSR-expressing breast cancer cells and exerts a rapid cytotoxic effect. This gives iota toxin great potential to be utilized as an immunotoxin for (i) transporting foreign proteins into targeted cells, (ii) modification to increase specificity to a specific cell type, and (iii) increasing drug absorption of chemotherapeutic drugs [32,67].

Two studies with another bacterial toxin, Clostridium perfringens enterotoxin (CPE), reveal that CPE specifically targets claudin-overexpressing mouse NT6 fibroblasts, human colorectal adenocarcinoma (Caco-2), colon (HCT116) and mammary (MCF-7) cell lines [22,23]. The study by Walther et al. utilized non-viral, intratumoral in vivo gene transfer of CPE into mice with MCF-7 and HCT116 xenografts, resulting in reduced tumor growth compared to control groups [22]. Translational explorations of $C$. perfringens iota toxin as a chemotherapeutic are yet to be exploited to date. A study by Sakurai and Kobayashi evaluated the role of Ia and Ib subunits in guinea pigs [68]. When Ib was injected intradermally and Ia intrapertoneally, Ia was able to specifically target the Ib component in the skin resulting in localized dermonecrosis without other side effects. These studies support the feasibility of iota toxin as a specific, localized tool for drug therapy. Importantly, unlike CPE, which has the risk of eliciting its toxic effects to normal claudin expressing cells, iota toxin has had no reported effects in humans $[68,69]$. When combined with aforementioned results from the Sakurai and Kobayashi study, targeted therapeutics against breast cancer derived from iota toxin may provide a welltolerated, effective alternative with lower off target effects compared to current targeted therapies.

\section{Conclusions}

Our data presents an interesting mechanism of iota toxin cytotoxicity in breast cancer. We demonstrate that LSR is the cell-surface protein that mediates iota toxin cytotoxicity through endocytosis in breast cancer cells, and propose a novel role for CD44 as a driver of resistance towards iota toxin via inhibition of endocytotic mechanisms. Furthermore, we are the first to describe LSR expression in tamoxifen-resistant breast cancer and show the potential of iota toxin as a tool to overcome cancer-stem cell like, pro-survival mechanisms and induce necrotic cell death. Collectively, our data uniquely show that iota toxin has the potential to become an effective, targeted adjuvant therapy for breast cancer and alternative to current treatment options. 


\section{Methods}

\section{Cell culture}

MCF-7, T47D, ZR-75-1, HCC1937, MDA-MB-468, BT20, HCC1143, MDA-MB-231, Hs578t, BT-549, AU565, SKBR3, M99005, MCF-10AI, MCF-10AIII, and MCF10AIV cells were obtained from American Type Culture Collection (ATCC; Manassas, VA). SUM159, SUM149, Sum190, and SUM1315mo cells were obtained from Asterand (Detroit, MI, USA). TMX2-4, TMX2-11 and TMX2-28 cells were a kind gift from Dr. Kathleen Arcaro (University of Massachusetts, Amherst). Cells were cultured according to manufacturer's recommendations and passaged via trypsinization when approximately $80 \%$ confluent.

\section{lota toxin, reagents, and toxicity testing}

Iota toxin components Ia and Ib were purified as described previously [70]. For toxin sensitivity assays, cells were seeded at $1-3 \times 10^{4}$ concentrations, enabling confluency $48 \mathrm{~h}$ later. Cells were then treated as either a control (10 $\mathrm{ng} \mathrm{Ia} / \mathrm{ml}$ ) or with varying concentrations of iota toxin (Ia $10 \mathrm{ng} / \mathrm{ml}+\mathrm{Ib} 20 \mathrm{ng} / \mathrm{ml}$; Ia $25 \mathrm{ng} / \mathrm{ml}+\mathrm{Ib}$ $50 \mathrm{ng} / \mathrm{ml}$; Ia $50 \mathrm{ng} / \mathrm{ml}$ + Ib $100 \mathrm{ng} / \mathrm{ml}$; Ia $100 \mathrm{ng} / \mathrm{ml}+\mathrm{Ib}$ $200 \mathrm{ng} / \mathrm{ml}$ ) and cultured under normal growth conditions. Observations to determine toxin sensitivity, indicated by a rounded morphology indicative of cell death, were made at $0,1,2,4,6$, and 8 h post treatment. For oleic acid assays, cells were treated in the presence or absence of $0.8 \mathrm{mM}$ oleic acid at $37^{\circ} \mathrm{C}, 30 \mathrm{~min}$ prior to added toxin. Images were obtained by Spot Advanced version 4.5 (Sterling Heights, Michigan).

\section{Generation of knockdown and overexpressing cell lines}

RFP containing $\mathrm{HuSH}$ shRNA plasmids containing Homo sapiens LSR specific shRNA and Myc-DDK-tagged TrueORF clones of Homo sapiens LSR and CD44 were obtained from OriGene Technologies (cat\# TF303412, RC223636, and RC221771; Rockville, MD). Cells were transfected using TurboFectin 8.0 (Thermo Scientific, Rockford, IL) according to manufacturer's instructions. For stable transfection, cells were passaged at a 1:10 dilution into fresh growth medium containing $2.5 \mu \mathrm{g} / \mathrm{ml}$ Puromycin or $500-900 \mu \mathrm{g} / \mathrm{ml}$ of G418 (Life Technologies, Grand Island, NY). Control cells were simultaneously transfected with an empty plasmid vector and selected in antibiotic-containing medium as described above.

\section{Western blot analysis}

Cells were lysed in RIPA Buffer (50 mM Tris Base, $150 \mathrm{mM} \mathrm{NaCl}, 1 \mathrm{mM}$ EDTA, 1\% NP40, 0.25\% sodium deoxycholate) supplemented with protease and phosphatase inhibitors (Halt ${ }^{\mathrm{TM}}$ Thermo Scientific, Rockford, IL). Equal protein concentrations of total cell lysates, as determined by the Coomassie Plus Protein Assay (Thermo
Scientific, Rockford, IL), were separated by SDS-PAGE. Proteins were transferred to nitrocellulose membranes (BioExpress, Kaysville, UT). Membranes were blocked in $5 \%$ non-fat milk in TBST $(1.0 \mathrm{M}$ Tris- $\mathrm{HCl}, 5.0 \mathrm{M}$ $\mathrm{NaCl}, 0.1 \%$ Tween) for $1 \mathrm{~h}$ at room temperature, then incubated with primary antibody against LSR (1:750; sc133765), HCAM (CD44; 1:500; sc-7297), E-cadherin (1:500; sc-7870; Santa Cruz Biotechnology, Santa Cruz, $\mathrm{CA})$, or anti-Ib (1:1000) overnight at $4^{\circ} \mathrm{C}$ in TBST containing 5\% BSA. Membranes were then washed and incubated with the appropriate secondary antibody conjugated to horseradish peroxidase (GE Healthcare, Piscataway, NJ) in TBST with $5 \%$ milk for $1 \mathrm{~h}$ at room temperature. Mouse monoclonal $\alpha$-tubulin antibody was used to evaluate equal protein loading across all lanes at a 1:5000 dilution (T6199; Sigma Aldrich, St. Louis, MO). WesternBright ECL Kit (Bioexpress, Kaysville, UT) was used to detect peroxidase activity. NIH Image J64 software was used to quantify western blots.

\section{Immunocytofluorescence}

Immunocytofluorescence was performed as previously described [71]. Briefly, cells were grown on 8-well chamber slides (Research Products International, Mt. Prospect, IL,) and fixed/permeabilized in ice-cold methanol:acetone. Following fixation, cells were blocked with 1\% BSA and $5 \%$ normal horse serum in PBS, stained with the indicated primary antibody (1:100 dilution of anti-LSR, sc-133765 or anti-HCAM (CD44), sc-7297) for $1 \mathrm{~h}$ at $4^{\circ}$, washed, and then incubated for $30 \mathrm{~min}$ with an anti-rabbit or anti-mouse Alexa Fluor 488 secondary antibody (1:1000 dilution, Invitrogen). Coverslips were applied with ProLong ${ }^{\circ}$ Gold Antifade Reagent and DAPI (Life Technologies). Imaging was performed on a Nikon DiaPhot microscope with digital camera and NIS-Elements 4.11.00 (Nikon Instruments Inc., Melville, NY). All cell lines and samples were obtained in compliance with the Helsinki Declaration and performed in accordance with the guidelines of the North Carolina Central University Institutional Review Board, approval 1201027.

\section{Glycosylation analysis}

Cells were grown under normal growth conditions until approximately $70 \%$ confluent, and then serum starved overnight. Cells were subsequently treated with $25 \mu \mathrm{g} / \mathrm{ml}$ of either Tunicamycin (MP Biomedical LLC, Solon, OH) or Swainsonine (Calbiochem, San Diego, CA), or vehicle control. Twenty-four hours post treatment, cell lysates were collected and analyzed via western blot analysis to determine glycosylation status of LSR.

\section{Lysosome detection assay}

Cells were grown under normal growth conditions until approximately $70 \%$ confluent. Cells were then treated as 
either a control (10 $\mathrm{ng} \mathrm{Ia} / \mathrm{ml})$, or with iota toxin consisting of Ia (100 ng/ml) plus Ib (200 ng/ml), and cultured under normal growth conditions for $30 \mathrm{~min}$. Following treatment, LysoTracker Green DND-26 (Cell Signaling Technology, Danvers, MA) was diluted 1:20,000 (50 nM) and added directly into growth medium, followed by imaging on a NIS-Elements 4.11.00. A minimum of three replicate wells was plated for each independent experiment, with a minimum of five fields imaged per well.

\section{Cell death assays}

Cells were seeded at $1-3 \times 10^{4}$ concentrations, obtaining confluency $48 \mathrm{~h}$ later. Cells were then treated as controls $(10 \mathrm{ng} \mathrm{Ia} / \mathrm{ml}$ ) or with iota toxin at low (Ia $10 \mathrm{ng} / \mathrm{ml}+\mathrm{Ib}$ $20 \mathrm{ng} / \mathrm{ml}$ ) or high (Ia $100 \mathrm{ng} / \mathrm{ml}+\mathrm{Ib} 200 \mathrm{ng} / \mathrm{ml}$ ) concentrations followed by culturing under normal growth conditions for $0,2,4,6$, and $8 \mathrm{~h}$. Post treatment, cytotoxicity was determined using a CytoTox-Fluor ${ }^{\text {Tu }}$ Cytotoxicity Assay (Promega, Madison, WI) per manufacturer's instructions.

\section{CD44 variant analysis}

RT-qPCR amplification reactions were conducted in duplicate using 1X Brilliant II SYBR ${ }^{\circ}$ Green QPCR MasterMix (Agilent Technologies, Cary, NC) in the presence of variant specific primers (800 $\mathrm{nM}$ each; Additional file 3: Table S2) and $40 \mathrm{ng}$ of cDNA (based on total RNA) in $20 \mu \mathrm{l}$. A non-template reaction was used as negative control. PCR conditions consisted of denaturation at $95^{\circ} \mathrm{C}$ for $10 \mathrm{~min}$, activation of the DNA polymerase, followed by 40 cycles of $95^{\circ} \mathrm{C}$ for 15 seconds and specific annealing temperatures for each splicing variant for $1 \mathrm{~min}$. Melting curves were generated after amplification at $95^{\circ} \mathrm{C}$ for 15 seconds, $60^{\circ} \mathrm{C}$ for 30 seconds and $95^{\circ} \mathrm{C}$ for 15 seconds. All reactions were conducted in a Stratagene Mx3005P detection system (Stratagene, La Jolla, CA). Amplification efficiency of each pair of primers was calculated using standard curve dilutions and incorporated into the calculation for relative expression differences as previously described [72]. The optimal normalization factor was calculated as the geometric mean of the reference targets B2M, SDHA, UBC and YWHAZ.

\section{LSR variant analysis}

RT-qPCR amplification reactions were conducted in duplicate using $1 \mathrm{X}$ Brilliant II SYBR ${ }^{\circ}$ Green QPCR MasterMix (Agilent Technologies, Cary, NC) in the presence of optimized variant specific primers (800 nM; Supplementary Table 1) and 100 ng of cDNA (based on total RNA) in $20 \mu \mathrm{l}$. A non-template reaction was used as negative control. PCR conditions were the same as those used for CD44 analysis. All reactions were conducted in an Applied Biosystems' 7500 Real Time PCR system (Grand Island, NY). Raw data were normalized to GAPDH and analyzed via the comparative $\mathrm{CT}\left({ }^{\Delta \Delta} \mathrm{CT}\right)$ method.

\section{Statistical analysis}

To evaluate toxin sensitivity, relative percent of cell rounding was determined via visualization using light microscopy for each treatment group and statistical significances between treatment groups and across cell lines was determined by student t-test using GraphPad Prism version 3.02 software (GraphPad Software Inc., San Diego, CA), significance was set at $\mathrm{P}<0.05$. Differences in statistical significance between cell lines regarding CD44 and LSR expression levels (total and variants), was determined by ANOVA and post-hoc two-tailed comparisons. Significance was set at $P<0.05$ and a Bonferonni correction was used to adjust the $P$-value of t-tests. Graphs were plotted in Microsoft Excel as mean \pm S.D.

\section{Additional files}

Additional file 1: Figure S1. Quantitation of iota toxin sensitivity by percent cell rounding. (A) Relative quantitation of cell rounding for Figure $1 C \& D$, (B) Figure 2, (C) Figure 3B, (D \& E) Figure 4C, (F) Figure 6B. A minimum of three independent experiments was performed for each analysis. ${ }^{*} P<0.05, \Delta$ indicates $P<0.05$ for comparison of the high toxin concentration (la $100 \mathrm{ng} / \mathrm{ml}+\mathrm{lb} 200 \mathrm{ng} / \mathrm{ml}$ ) to the low toxin concentration (la $10 \mathrm{ng} / \mathrm{ml}+\mathrm{lb} 20 \mathrm{ng} / \mathrm{ml}$ ).

Additional file 2: Figure S2. Glycosylation of LSR does not play a role in toxin sensitivity. (A) MCF-7 cells were grown under normal growth conditions until approximately $70 \%$ confluence. Cells were then serum starved overnight followed by treatment with $25 \mu \mathrm{g} / \mathrm{ml}$ of Tunicamycin, Swainsonine, or vehicle control in normal growth medium. Twenty-four hours post treatment, cell lysates were collected and western blot analysis was performed to determine glycosylation status of LSR. (B) MCF-7 and Hs578t cells were serum starved overnight, $24 \mathrm{~h}$ post seeding then treated $48 \mathrm{~h}$ post seeding with toxin and either vehicle control or $25 \mathrm{\mu g} /$ $\mathrm{ml}$ Tunicamycin. Rounding and detachment indicated cell death.

Additional file 3: Tables S1. lota Toxin Sensitivity of Cells Following Tunicamycin Treatment. Table S2. Primers used to detect splice variants.

Additional file 4: Figure S3. CD44 variant expression does not correlate with toxin sensitivity. Relative CD44 expression was determined for seven splice variants using real time qRT-PCR. Data were normalized to the geometric mean of the reference targets $B 2 M, S D H A, U B C$ and YWHAZ. A minimum of three independent experiments was performed for each analysis.

Additional file 5: Figure S4. LSR variant expression and two LSRrelated proteins, ILDR1 and ILDR2, do not correlate with toxin sensitivity. Relative LSR expression was determined for five splice variants using real time qRT-PCR as well as the two LSR-related proteins, immunoglobulin-like domain-containing receptor (ILDR) 1 and ILDR2. ILDR2 was not detected in any breast cancer samples but readily detected in monocyte cell line, THP-1 (bottom right panel; representative ethidium bromide stained DNA gel). Data were normalized to GAPDH. A minimum of three independent experiments was performed for each analysis.

\section{Abbreviations}

LSR: Lipolysis stimulated lipoprotein receptor; ERa: Estrogen receptor alpha; HER2: Human epidermal growth factor receptor 2.

\section{Competing interests}

The authors declare that they have no competing interests.

\section{Authors' contributions}

JMF and BGS conceived and designed the study; KFS, DKR, MCR, and JMF performed the experiments; BGS, and JMF analyzed and interpreted data; MRP supervised the study; KFS, BGS, JMF wrote the paper. All authors read and approved the final manuscript. 


\section{Acknowledgements}

This work was supported by the National Cancer Institute (U54 CA156735 and R21 CA175783) and the National Institute to General Medical Sciences (SC2 GM102012). The authors thank Dr. Kathleen Arcaro from the University of Massachusetts Amherst for kindly provided TMX2-4, TMX2-11, and TMX2-28 cell lines.

\section{Author details}

'Department of Biology, North Carolina Central University, Durham, NC, USA. ${ }^{2}$ Tumor Growth Factor Section, Laboratory of Cancer Prevention, Frederick National Laboratory for Cancer Research, Frederick, MD, USA. Institut Pasteur, Anaerobic Bacteria and Toxins Unit, Paris, France. ${ }^{4}$ Department of Biology, Wilson College, Chambersburg, PA, USA.

Received: 15 April 2014 Accepted: 24 June 2014

Published: 2 July 2014

\section{References}

1. Carey LA, Dees EC, Sawyer L, Gatti L, Moore DT, Collichio F, Ollila DW, Sartor $\mathrm{Cl}$, Graham ML, Perou CM: The triple negative paradox: primary tumor chemosensitivity of breast cancer subtypes. Clin Cancer Res 2007, 13:2329-2334.

2. Perou CM, Parker JS, Prat A, Ellis MJ, Bernard PS: Clinical implementation of the intrinsic subtypes of breast cancer. Lancet Oncol 2010, 11:718-719. author reply 720-711.

3. Prat A, Parker JS, Karginova O, Fan C, Livasy C, Herschkowitz Jl, He X, Perou CM: Phenotypic and molecular characterization of the claudin-low intrinsic subtype of breast cancer. Breast Cancer Res 2010, 12:R68.

4. Rouzier R, Pusztai L, Delaloge S, Gonzalez-Angulo AM, Andre F, Hess KR, Buzdar AU, Garbay JR, Spielmann M, Mathieu MC, Symmans WF, Wagner P, Atallah D, Valero V, Berry DA, Hortobagyi GN: Nomograms to predict pathologic complete response and metastasis-free survival after preoperative chemotherapy for breast cancer. J Clin Oncol 2005, 23:8331-8339.

5. Sorlie T, Perou CM, Tibshirani R, Aas T, Geisler S, Johnsen H, Hastie T, Eisen $M B$, van de Rijn M, Jeffrey SS, Thorsen T, Quist $H$, Matese JC, Brown PO, Botstein D, Lonning PE, Borresen-Dale AL: Gene expression patterns of breast carcinomas distinguish tumor subclasses with clinical implications. Proc Natl Acad Sci U S A 2001, 98:10869-10874.

6. Sorlie T, Tibshirani R, Parker J, Hastie T, Marron JS, Nobel A, Deng S, Johnsen H, Pesich R, Geisler S, Demeter J, Perou CM, Lonning PE, Brown PO, Borresen-Dale AL, Botstein D: Repeated observation of breast tumor subtypes in independent gene expression data sets. Proc Natl Acad Sci U S A 2003, 100:8418-8423.

7. Cheang MC, Voduc D, Bajdik C, Leung S, McKinney S, Chia SK, Perou CM, Nielsen TO: Basal-like breast cancer defined by five biomarkers has superior prognostic value than triple-negative phenotype. Clin Cancer Res 2008, 14:1368-1376.

8. Rakha EA, Elsheikh SE, Aleskandarany MA, Habashi HO, Green AR, Powe DG, El-Sayed ME, Benhasouna A, Brunet JS, Akslen LA, Evans AJ, Blamey R, ReisFilho JS, Foulkes WD, Ellis IO: Triple-negative breast cancer: distinguishing between basal and nonbasal subtypes. Clin Cancer Res 2009, $15: 2302-2310$

9. Perou CM, Borresen-Dale AL: Systems biology and genomics of breast cancer. Cold Spring Harb Perspect Biol 2011, 3(2):a003293.

10. Allred DC, Brown P, Medina D: The origins of estrogen receptor alphapositive and estrogen receptor alpha-negative human breast cancer. Breast Cancer Res 2004, 6:240-245.

11. Dunnwald LK, Rossing MA, Li Cl: Hormone receptor status, tumor characteristics, and prognosis: a prospective cohort of breast cancer patients. Breast Cancer Res 2007, 9:R6.

12. Ponta H, Sherman L, Herrlich PA: CD44: from adhesion molecules to signalling regulators. Nat Rev Mol Cell Biol 2003, 4:33-45.

13. Herbsleb M, Birkenkamp-Demtroder K, Thykjaer T, Wiuf C, Hein AM, Orntoft $T F$, Dyrskjot $L$ : Increased cell motility and invasion upon knockdown of lipolysis stimulated lipoprotein receptor (LSR) in SW780 bladder cancer cells. BMC Med Genomics 2008, 1:31.

14. Leth-Larsen R, Terp MG, Christensen AG, Elias D, Kuhlwein T, Jensen ON, Petersen OW, Ditzel HJ: Functional heterogeneity within the CD44 high human breast cancer stem cell-like compartment reveals a gene signature predictive of distant metastasis. Mol Med 2012, 18:1109-1121.
15. Meyer MJ, Fleming JM, Lin AF, Hussnain SA, Ginsburg E, Vonderhaar BK: CD44posCD49fhiCD133/2hi defines xenograft-initiating cells in estrogen receptor-negative breast cancer. Cancer Res 2010, 70:4624-4633.

16. Zoller M: CD44: can a cancer-initiating cell profit from an abundantly expressed molecule? Nat Rev Cancer 2011, 11:254-267.

17. Ricardo S, Vieira AF, Gerhard R, Leitao D, Pinto R, Cameselle-Teijeiro JF, Milanezi F, Schmitt F, Paredes J: Breast cancer stem cell markers CD44, CD24 and ALDH1: expression distribution within intrinsic molecular subtype. J Clin Pathol 2011, 64:937-946.

18. Stratford AL, Reipas K, Maxwell C, Dunn SE: Targeting tumour-initiating cells to improve the cure rates for triple-negative breast cancer. Expert Rev Mol Med 2010, 12:e22.

19. Giatromanolaki A, Sivridis E, Fiska A, Koukourakis MI: The CD44+/CD24phenotype relates to 'triple-negative' state and unfavorable prognosis in breast cancer patients. Med Oncol 2011, 28:745-752.

20. Tiezzi DG, Valejo FA, Marana HR, Carrara HH, Benevides L, Antonio HM, Sicchieri RD, Milanezi CM, Silva JS, de Andrade JM: CD44(+)/CD24 (-) cells and lymph node metastasis in stage I and II invasive ductal carcinoma of the breast. Med Oncol 2012, 29:1479-1485.

21. Reaves DK, Fagan-Solis KD, Dunphy K, Oliver SD, Scott DW, Fleming JM: The role of lipolysis stimulated lipoprotein receptor in breast cancer and directing breast cancer cell behavior. PLOS ONE 2014, 9:e91747.

22. Walther W, Petkov S, Kuvardina ON, Aumann J, Kobelt D, Fichtner I, Lemm M, Piontek J, Blasig IE, Stein U, Schlag PM: Novel Clostridium perfringens enterotoxin suicide gene therapy for selective treatment of claudin-3and -4-overexpressing tumors. Gene Ther 2012, 19:494-503.

23. Shrestha A, McClane BA: Human claudin- 8 and -14 are receptors capable of conveying the cytotoxic effects of Clostridium perfringens enterotoxin. MBio 2013, 4:E00594-12.

24. Michl P, Gress TM: Bacteria and bacterial toxins as therapeutic agents for solid tumors. Curr Cancer Drug Targets 2004, 4:689-702.

25. Lee EJ, Jameson JL: Cell-specific Cre-mediated activation of the diphtheria toxin gene in pituitary tumor cells: potential for cytotoxic gene therapy. Hum Gene Ther 2002, 13:533-542.

26. Zheng JY, Chen D, Chan J, Yu D, Ko E, Pang S: Regression of prostate cancer xenografts by a lentiviral vector specifically expressing diphtheria toxin A. Cancer Gene Ther 2003, 10:764-770.

27. Candolfi M, Xiong W, Yagiz K, Liu C, Muhammad AK, Puntel M, Foulad D, Zadmehr A, Ahlzadeh GE, Kroeger KM, Tesarfreund M, Lee S, Debinski W, Sareen D, Svendsen CN, Rodriguez R, Lowenstein PR, Castro MG: Gene therapy-mediated delivery of targeted cytotoxins for glioma therapeutics. Proc Natl Acad Sci U S A 2010, 107:20021-20026.

28. Laske DW, Youle RJ, Oldfield EH: Tumor regression with regional distribution of the targeted toxin TF-CRM107 in patients with malignant brain tumors. Nat Med 1997, 3:1362-1368.

29. Husain SR, Puri RK: Interleukin-13 receptor-directed cytotoxin for malignant glioma therapy: from bench to bedside. J Neurooncol 2003, 65:37-48.

30. Ayesh B, Matouk I, Ohana P, Sughayer MA, Birman T, Ayesh S, Schneider T, de Groot N, Hochberg A: Inhibition of tumor growth by DT-A expressed under the control of IGF2 P3 and P4 promoter sequences. Mol Ther 2003, 7:535-541.

31. Simpson LL, Stiles BG, Zepeda HH, Wilkins TD: Molecular basis for the pathological actions of Clostridium perfringens iota toxin. Infect Immun 1987, 55:118-122.

32. Barth $H$, Stiles BG: Binary actin-ADP-ribosylating toxins and their use as molecular Trojan horses for drug delivery into eukaryotic cells. Curr Med Chem 2008, 15:459-469.

33. Vandekerckhove J, Schering B, Barmann M, Aktories K: Clostridium perfringens iota toxin ADP-ribosylates skeletal muscle actin in Arg-177. FEBS Lett 1987, 225:48-52.

34. Hilger H, Pust S, von Figura G, Kaiser E, Stiles BG, Popoff MR, Barth H: The long-lived nature of clostridium perfringens iota toxin in mammalian cells induces delayed apoptosis. Infect Immun 2009, 77:5593-5601.

35. Papatheodorou P, Carette JE, Bell GW, Schwan C, Guttenberg G Brummelkamp TR, Aktories K: Lipolysis-stimulated lipoprotein receptor (LSR) is the host receptor for the binary toxin Clostridium difficile transferase (CDT). Proc Natl Acad Sci U S A 2011, 108:16422-16427.

36. Wigelsworth DJ, Ruthel G, Schnell L, Herrlich P, Blonder J, Veenstra TD, Carman RJ, Wilkins TD, Van Nhieu GT, Pauillac S, Gibert M, Sauvonnet N, Stiles BG, Popoff MR, Barth H: CD44 promotes intoxication by the clostridial iota-family toxins. PLOS ONE 2012, 7:e51356. 
37. Mann CJ, Khallou J, Chevreuil O, Troussard AA, Guermani LM, Launay K, Delplanque B, Yen FT, Bihain BE: Mechanism of activation and functional significance of the lipolysis-stimulated receptor. Evidence for a role as chylomicron remnant receptor. Biochemistry 1995, 34:10421-10431.

38. Yen FT, Mann CJ, Guermani LM, Hannouche NF, Hubert N, Hornick CA, Bordeau VN, Agnani G, Bihain BE: Identification of a lipolysis-stimulated receptor that is distinct from the LDL receptor and the LDL receptorrelated protein. Biochemistry 1994, 33:1172-1180.

39. Yen FT, Masson M, Clossais-Besnard N, Andre P, Grosset JM, Bougueleret L, Dumas JB, Guerassimenko O, Bihain BE: Molecular cloning of a lipolysisstimulated remnant receptor expressed in the liver. J Biol Chem 1999, 274:13390-13398.

40. Bennett KL, Modrell B, Greenfield B, Bartolazzi A, Stamenkovic I, Peach R, Jackson DG, Spring F, Aruffo A: Regulation of CD44 binding to hyaluronan by glycosylation of variably spliced exons. J Cell Biol 1995, 131:1623-1633.

41. Bartolazzi A, Nocks A, Aruffo A, Spring F, Stamenkovic I: Glycosylation of CD44 is implicated in CD44-mediated cell adhesion to hyaluronan. J Cell Biol 1996, 132:1199-1208.

42. Skelton TP, Zeng C, Nocks A, Stamenkovic I: Glycosylation provides both stimulatory and inhibitory effects on cell surface and soluble CD44 binding to hyaluronan. J Cell Biol 1998, 140:431-446.

43. Zhao H, Liang Y, Xu Z, Wang L, Zhou F, Li Z, Jin J, Yang Y, Fang Z, Hu Y, Zhang L, Su J, Zha X: N-glycosylation affects the adhesive function of E-Cadherin through modifying the composition of adherens junctions (AJs) in human breast carcinoma cell line MDA-MB-435. J Cell Biochem 2008, 104:162-175.

44. Liwosz A, Lei T, Kukuruzinska MA: N-glycosylation affects the molecular organization and stability of E-cadherin junctions. J Biol Chem 2006, 281:23138-23149.

45. Olsson E, Honeth G, Bendahl PO, Saal LH, Gruvberger-Saal S, Ringner M, Vallon-Christersson J, Jonsson G, Holm K, Lovgren K, Ferno M, Grabau D, Borg A, Hegardt C: CD44 isoforms are heterogeneously expressed in breast cancer and correlate with tumor subtypes and cancer stem cell markers. BMC Cancer 2011, 11:418.

46. Higashi T, Tokuda S, Kitajiri S, Masuda S, Nakamura H, Oda Y, Furuse M: Analysis of the 'angulin' proteins LSR, ILDR1 and ILDR2-tricellulin recruitment, epithelial barrier function and implication in deafness pathogenesis. J Cell Sci 2013, 126:966-977.

47. Ponta H, Sleeman J, Dall P, Moll J, Sherman L, Herrlich P: CD44 isoforms in metastatic cancer. Invasion Metastasis 1994, 14:82-86.

48. O'Driscoll L, Clynes M: Biomarkers and multiple drug resistance in breast cancer. Curr Cancer Drug Targets 2006, 6:365-384.

49. Musgrove EA, Sutherland RL: Biological determinants of endocrine resistance in breast cancer. Nat Rev Cancer 2009, 9:631-643.

50. Clarke R, Liu MC, Bouker KB, Gu Z, Lee RY, Zhu Y, Skaar TC, Gomez B, O'Brien $K$, Wang $Y$, Hilakivi-Clarke LA: Antiestrogen resistance in breast cancer and the role of estrogen receptor signaling. Oncogene 2003, 22:7316-7339.

51. (EBCTCG) EBCTCG: Effects of chemotherapy and hormonal therapy for early breast cancer on recurrence and 15-year survival: an overview of the randomised trials. Lancet 2005, 365:1687-1717.

52. Thankamony SP, Knudson W: Acylation of CD44 and its association with lipid rafts are required for receptor and hyaluronan endocytosis. $J$ Biol Chem 2006, 281:34601-34609.

53. Dubois F, Vandermoere F, Gernez A, Murphy J, Toth R, Chen S, Geraghty KM, Morrice NA, MacKintosh C: Differential 14-3-3 affinity capture reveals new downstream targets of phosphatidylinositol 3-kinase signaling. Mol Cell Proteomics 2009, 8:2487-2499.

54. Gibert M, Monier MN, Ruez R, Hale ML, Stiles BG, Benmerah A, Johannes L, Lamaze C, Popoff MR: Endocytosis and toxicity of clostridial binary toxins depend on a clathrin-independent pathway regulated by Rho-GDI. Cell Microbiol 2011, 13:154-170

55. Palaniyandi K, Pockaj BA, Gendler SJ, Chang XB: Human breast cancer stem cells have significantly higher rate of clathrin-independent and caveolinindependent endocytosis than the differentiated breast cancer cells. J Cancer Sci Ther 2012, 4:214-222.

56. Nagahama M, Umezaki M, Tashiro R, Oda M, Kobayashi K, Shibutani M Takagishi T, Ishidoh K, Fukuda M, Sakurai J: Intracellular trafficking of Clostridium perfringens iota-toxin b. Infect Immun 2012, 80:3410-3416.

57. Richard JF, Mainguy G, Gibert M, Marvaud JC, Stiles BG, Popoff MR: Transcytosis of iota-toxin across polarized CaCo-2 cells. Mol Microbiol 2002, 43:907-917.
58. Tilghman SL, Townley I, Zhong Q, Carriere PP, Zou J, Llopis SD, Preyan LC, Williams CC, Skripnikova E, Bratton MR, Zhang Q, Wang G: Proteomic signatures of acquired letrozole resistance in breast cancer: suppressed estrogen signaling and increased cell motility and invasiveness. Mol Cell Proteomics 2013, 12:2440-2455.

59. Hanamura T, Niwa T, Nishikawa S, Konno H, Gohno T, Tazawa C, Kobayashi Y, Kurosumi M, Takei H, Yamaguchi Y, Ito K, Hayashi S: Androgen metabolite-dependent growth of hormone receptor-positive breast cancer as a possible aromatase inhibitor-resistance mechanism. Breast Cancer Res Treat 2013, 139:731-740.

60. Wong C, Chen S: The development, application and limitations of breast cancer cell lines to study tamoxifen and aromatase inhibitor resistance. J Steroid Biochem Mol Biol 2012, 131:83-92.

61. Chang M: Tamoxifen resistance in breast cancer. Biomol Ther (Seoul) 2012, 20:256-267.

62. Pastan I, Hassan R, FitzGerald DJ, Kreitman RJ: Immunotoxin treatment of cancer. Annu Rev Med 2007, 58:221-237.

63. Yang RS, Chang LW, Yang CS, Lin P: Pharmacokinetics and physiologicallybased pharmacokinetic modeling of nanoparticles. J Nanosci Nanotechnol 2010, 10:8482-8490

64. Azemar M, Djahansouzi S, Jager E, Solbach C, Schmidt M, Maurer AB, Mross K, Unger C, von Minckwitz G, Dall P, Groner B, Wels WS: Regression of cutaneous tumor lesions in patients intratumorally injected with a recombinant single-chain antibody-toxin targeted to ErbB2/HER2. Breast Cancer Res Treat 2003, 82:155-164.

65. von Minckwitz G, Harder S, Hovelmann S, Jager E, Al-Batran SE, Loibl S, Atmaca A, Cimpoiasu C, Neumann A, Abera A, Knuth A, Kaufmann M, Jager $D$, Maurer AB, Wels WS: Phase I clinical study of the recombinant antibody toxin scFv(FRP5)-ETA specific for the ErbB2/HER2 receptor in patients with advanced solid malignomas. Breast Cancer Res 2005, 7:R617-R626.

66. Kreitman RJ, Hassan R, Fitzgerald DJ, Pastan I: Phase I trial of continuous infusion anti-mesothelin recombinant immunotoxin SS1P. Clin Cancer Res 2009, 15:5274-5279.

67. Marvaud JC, Smith T, Hale ML, Popoff MR, Smith LA, Stiles BG: Clostridium perfringens iota-toxin: mapping of receptor binding and la docking domains on Ib. Infect Immun 2001, 69:2435-2441.

68. Sakurai J, Kobayashi K: Lethal and dermonecrotic activities of Clostridium perfringens lota toxin: biological activities induced by cooperation of two nonlinked components. Microbiol Immunol 1995, 39:249-253.

69. Songer JG: Clostridial enteric diseases of domestic animals. Clin Microbiol Rev 1996, 9:216-234

70. Perelle S, Scalzo S, Kochi S, Mock M, Popoff MR: Immunological and functional comparison between Clostridium perfringens iota toxin, C. spiroforme toxin, and anthrax toxins. FEMS Microbiol Lett 1997, 146:117-121.

71. Fleming JM, Ginsburg E, McAndrew CW, Heger CD, Cheston L, RodriguezCanales J, Vonderhaar BK, Goldsmith P: Characterization of $\Delta 7 / 11$, a functional prolactin-binding protein. J Mol Endocrinol 2013, 50:79-90.

72. Pfaffl MW: A new mathematical model for relative quantification in real-time RT-PCR. Nucleic Acids Res 2001, 29:e45.

doi:10.1186/1476-4598-13-163

Cite this article as: Fagan-Solis et al: Challenging the roles of CD44 and lipolysis stimulated lipoprotein receptor in conveying Clostridium perfringens iota toxin cytotoxicity in breast cancer. Molecular Cancer 2014 13:163. 